\title{
A pluri- és multipotencia határán: a ganglionléc össejtjei
}

\author{
Kudlik Gyöngyi PhD-hallgató ${ }^{1}$ - Matula Zsolt PhD-hallgató ${ }^{1}$ \\ Kovács Tamás egyetemi hallgató ${ }^{1}$ \\ Urbán S. Veronika dr. ${ }^{2}$. Uher Ferenc dr. ${ }^{3}$ \\ ${ }^{1}$ Magyar Tudományos Akadémia, Természettudományi Kutatóközpont, Enzimológiai Intézet, Budapest \\ ${ }^{2}$ Semmelweis Egyetem, Egészségtudományi Kar, Morfológiai és Fiziológiai Tanszék, Budapest \\ ${ }^{3}$ Országos Vérellátó Szolgálat, Budapest
}

\begin{abstract}
A ganglionléc a gerinces embriókban megjelenő átmeneti, multipotens, vándorló sejtpopuláció, amiből a perifériás idegrendszer idegi és gliális elemeitől kezdve a craniofacialis terület ectomesenchymalis származékain vagy a bőr pigmentsejtjein át számos struktúra származtatható. Érdekes módon a ganglionléc-eredetű őssejtek nem csak az embrionális ganglionlécben vannak jelen, hanem megtalálhatók az általuk betelepített embrionális és felnőttkori szövetekben is. Ezek a posztmigrációs őssejtek - legalábbis részlegesen - tükrözik elődeik multipotenciáját. Ráadásul az olyan ganglionléc-eredetű, terminálisan differenciálódott sejtek, mint például a Schwann-sejtek és a melanocyták, bármikor képesek őssejtszerú progenitorokká dedifferenciálódni. Az összefoglaló tanulmányban a szerző́k bemutatják, hogy mit tudunk jelenleg ezekrôl a különleges plaszticitású ôssejtekről és milyen potenciális alkalmazási lehetőségek merülnek fel velük kapcsolatban a regeneratív orvoslás területén. Orv. Hetil., 2015, 156(42), 1683-1694.
\end{abstract}

Kulcsszavak: ectomesenchyma, ganglionléc, őssejtek, plaszticitás

\begin{abstract}
At the border of pluri- and multipotency: the neural crest stem cells
The neural crest is a transient, multipotent, migratory cell population that is unique to vertebrate embryos and gives rise to many derivatives, ranging from the neuronal and glial components of the peripheral nervous system to the ectomesenchymal derivatives of the craniofacial area and pigment cells in the skin. Intriguingly, the neural crest derived stem cells are not only present in the embryonic neural crest, but also in their target tissues in the fetus and adult. These postmigratory stem cells, at least partially, resemble their multipotency. Moreover, fully differentiated neural crest-derived cells such as Schwann cells and melanocytes are able to dedifferentiate into stem-like progenitors. Here the authors review current understanding of this unique plasticity and its potential application in stem cell biology as well as in regenerative medicine.
\end{abstract}

Keywords: ectomesenchyme, neural crest, plasticity, stem cells

Kudlik, Gy., Matula, Zs., Kovács, T., Urbán, S. V., Uher, F. [At the border of pluri- and multipotency: the neural crest stem cells]. Orv. Hetil., 2015, 156(42), 1683-1694.

(Beérkezett: 2015. július 29.; elfogadva: 2015. augusztus 28.)

\section{Rövidítések}

$\mathrm{BMP}=$ csont morfogenetikus fehérje; CFP = kék színú fluoreszcens fehérje; CIL = sejtek mozgásának kontakt gátlása; DRG = dorsalis gyökérdúcok; EGF = epidermalis növekedési faktor; EMT = epithelialis-mesenchymalis tranzíció; Eph = ephrinreceptor; ER = ösztrogénreceptor; FGF = fibroblastnövekedési faktor; GDNF = gliaeredetű növekedési faktor;
GFAP = gliális fibrilláris savanyú fehérje; GFP = zöld fluoreszcens fehérje; IL = interleukin; LIF = leukaemiagátló faktor; MCP-1 = monocyta kemotaktikus fehérje-1; MSC = mesenchymalis őssejt; $\mathrm{NC}=$ ganglionléc $;$ NCSC = ganglionlécőssejt; NGF = idegi eredetű növekedési faktor; PDGF = vérlemezkeeredetű növekedési faktor; R26R = Rosa26 riporter gén(komplex) 
A dolgozatban előforduló fontosabb gének nevének feloldása

Ascl = Achaete-Scute family BHLH transcription factor; Barx = BARX homeobox; Dlxl-7 = distal-less homeobox 1-7; Ebfl = early B-cell factor 1 (olfactory neuronal transcription factor 1); Ets $1=$ V-ets avian erythroblastosis virus E26 oncogene homolog 1; FoxD3 = forkhead box D3; Gbx2 = gastrulation brain homeobox 2; Hoxa = homeobox A cluster; Hoxb = homeobox $\mathrm{B}$ cluster; Hoxc = homeobox $\mathrm{C}$ cluster; Hoxd = homeobox D cluster; Mitf $=$ microphthalmia-associated transcription factor; $M s x \mathrm{I}=$ Msh homeobox $\mathrm{l} ; M y b=\mathrm{V}-\mathrm{Myb}$ avian myeloblastosis viral oncogene homolog; $M y c=\mathrm{V}-\mathrm{Myc}$ avian myelocytomatosis viral oncogene homolog; Nanog = Nanog homeobox; Otx2 $=$ orthodenticle homeobox $2 ; \operatorname{Pax} 3 / 7=$ paired box $3 / 7$; Phox $2 b$ = paired-like homeobox $2 \mathrm{~b}$ (neuroblastoma pairedtype homeobox protein); Pou $5 F 1=$ POU class 5 homeobox 1 ; $\operatorname{Rxr} G=$ retinoid $\mathrm{X}$ receptor, gamma; Snaill $/ 2=$ snail family zinc finger $1 / 2$; Sox2-10 $=$ SRY (sex determining region $\mathrm{Y}$ )Box $5-10 ;$ Tfap 2 = transcription factor AP-2 alpha (activating enhancer binding protein 2 alpha); Twist1 = twist family BHLH transcription factor $1 ; \mathrm{Zicl}=$ zic family member 1

Az őssejteket differenciálódási képességük (potenciáljuk) alapján két nagy csoportra oszthatjuk. A beágyazódás előtti blastocysta belső sejtcsomójából (embryoblast) izolálható, úgynevezett embrionális őssejtek pluripotensek, azaz mindhárom csíralemez - ecto-, meso- és endoderma - irányába képesek differenciálódni, így az embriótest minden szövetét és szervét képesek létrehozni. A szervezetünkben felnőttkorban is megtalálható szöveti őssejtek ezzel szemben már csak multipotensek, egy-egy szövetet, esetleg szervet alkotó különböző típusú sejtekké képesek differenciálódni. A haematopoeticus őssejtekből például legalább hétféle érett vérsejt, a neuronalis őssejtekbőll neuronok és gliasejtek keletkeznek. Fiziológiás körülmények között a szöveti őssejtek biztosítják az adott szövet folyamatos megújulását, azaz pótolják az elöregedett, pusztuló testi sejteket, sérülés esetén pedig részt vesznek az érintett szerv regenerációjában [1]. Ugyanakkor minden gerinces egyedfejlődésének korai szakaszában megjelenik egy átmeneti, a ganglionlécet (neural crest, crista neuralis - NC) alkotó óssejtpopuláció is, amelynek tagjai egészen különleges - csak a tumorsejtekéhez hasonlítható - inváziós és migrációs képességgel rendelkeznek. Így az embrió szinte minden szervébe eljutnak, ahol - elsősorban az adott szöveti mikrokörnyezet hatására - ideg- és gliasejtekké, vázelemekké (csonttá és porccá), kötőszövetté, endokrin sejtekké vagy melanocytákká differenciálódhatnak. E széles plaszticitású - a szakirodalomban általában csak multipotensként definiált - őssejtek fejlődésbiológiai és nem utolsósorban orvosi jelentőségét az adja, hogy a craniofacialis területet érintő születési rendellenességek tetemes része az NC-eredetű sejtek fejlődésének és/vagy múködésének a zavarára vezethető vissza. Ráadásul ezek a rendellenességek, az arckoponya különböző mértékü deformitásai mellett, gyakran olyan létfontosságú szerveket is érintenek, mint az autonóm idegrendszer, az ér- zékszervek vagy a cardiovascularis rendszer. Példaként elég megemlíteni az Axenfeld-Rieger-, a CHARGE, a DiGeorge-, a Goldenhar-, a Treacher Collins- és a Waardenburg-szindrómákat. De ganglionléc-eredetû a Hirschsprung-betegség is, ami az NC-sejtek hibás migrációjának a következménye. A malignus megbetegedések közül a melanomát és a neuroblastomát kell kiemelni, mint NC-eredetû tumorokat $[2,3]$.

\section{A ganglionléc fejlődése}

A ganglionléc a gerincesek embriogenezise során az ectodermában, a velőlemez (lamina neuralis) és a nem neuralis (epidermalis) ectoderma határán alakul ki (1. A $a ́ b r a)$. A neurulatio folyamán a velőredő́k és a velóbarázda létrejöttével ez a határterület felemelkedik (1. B ábra), majd a velöcső (canalis neuralis) záródásával és besüllyedésével az NC a velőcső dorsalis felszínére kerül. A következő lépésben a ganglionlécre jellemző géneket (Foxd3 és Sox10) kifejező sejtek leválnak a velőcsőrőll (delamináció) (1. C ábra), és az ezzel szinte egy időben végbemenő epithelialis-mesenchymalis tranzíció (EMT) után az embrió különböző - sokszor igen távoli - részeibe vándorolnak ( 1 . D ábra), ahol az adott mikrokörnyezet hatására fokozatosan különböző ős- és/vagy testi sejtekké differenciálódnak. Olyan, rendkívül eltérő funkciójú szövetek, illetve szervek kialakításában vesznek részt, mint például a craniofacialis vázrendszer vagy a perifériás idegrendszer érző- és autonóm dúcai. De NCeredetű́ek a szem és a bőr pigmentsejtjei is [4]. A különböző, ganglionléc-eredetû sejtpopulációk vándorlásának részletes feltérképezését, valamint a belőlük származó sejtek egyértelmú azonosítását - többek között - a korszerü sejtfejlődésisor-követési (lineage tracing) módszerek alkalmazása tette lehetővé. Kiderült, hogy az NC a test hossztengelye mentén több, részben azonos, részben csak az adott ganglionléc-régióra jellemzó testi sejt létrehozására képes őssejt-populációból áll. Az NC feji, az elő-, közép- és utóagy magasságában húzódó szakaszát alkotó ôssejtekből jön létre például a craniofacialis váz (porc és csontszövet), az arctájék lágy szövetei (kötô" és zsíszövet), a fogak, az arcbőr, valamint egyes agyidegek gliasejtjei és érződúcai. Az NC következő, nyaki régióját alkotó őssejtek, illetve származékaik a szív egyes részeinek (aorticopulmonalis septum és conotruncalis párna), a szívből kilépő nagyerek falának és az enteralis dúcoknak a kialakításában vesznek részt. Az NC törzsi régiójából kivándorló sejtek hozzák létre a dorsalis gyökérdúcok (dorsal root ganglia - DRG) láncolatát, a perifériás idegrendszer szimpatikus dúcait, a Schwann-sejteket és a mellékvesevelő kromaffin sejtjeit. Melanocyta irányba viszont a ganglionléc minden őssejtje képes differenciálódni [5].

Az elmúlt években számos modellállat - zebrahal ( $D a$ nio rerio), afrikai karmosbéka (Xenopus laevis), csirke (Gallus gallus domesticus), egér (Mus musculus) és patkány (Rattus norvegicus) - embriogenezisének összeha- 
A

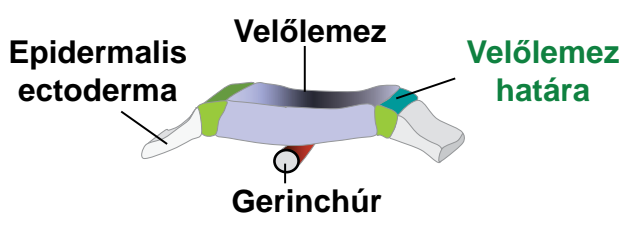

B

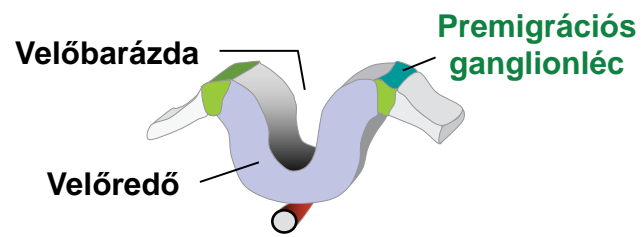

C

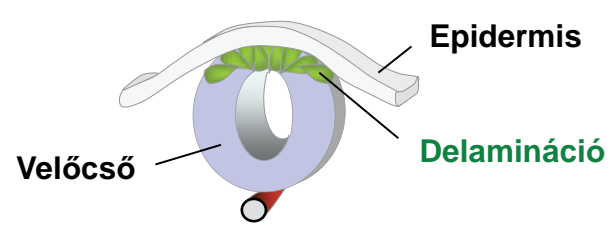

D

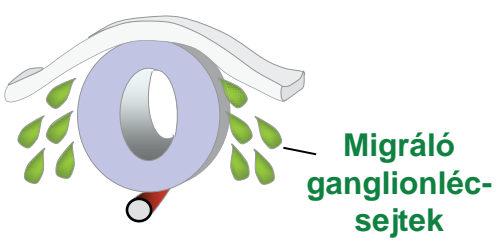

1. ábra

| A ganglionléc kialakulása és fejlődése [4, 7]
E

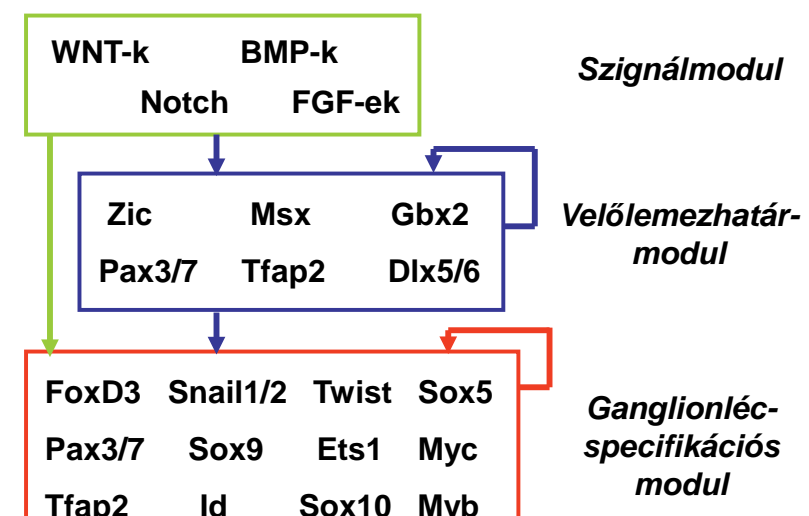
modul

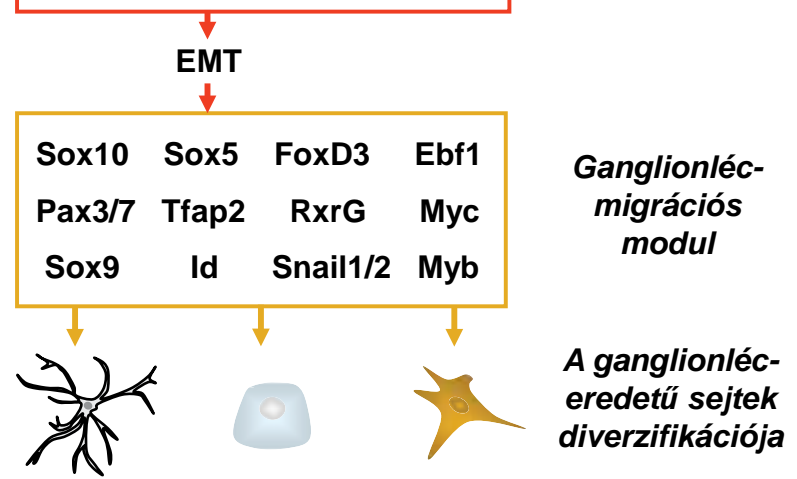

delamináció elófeltétele az NC-sejtek közti adhéziós övek (zonula adherens) fellazulása, illetve eltúnése, ami lehetôvé teszi, hogy a ganglionlécet alkotó (premigrációs) epithelsejtek egyedi elmozdulásra képes sejtekké váljanak szét. A folyamat molekuláris alapja a cadherin gének kifejeződésének változása. $\mathrm{Az}$ epithelsejtekre jellemző l-es típusú cadherineket (E-cad és $\mathrm{N}$-cad) a jóval gyengébb sejtkölcsönhatást biztosító, inkább a migráló sejtekre jellemző 2-es típusú cadherinek (cad-7 és cad-11) váltják fel az NC-sejtek felszínén. A cadherin gének kifejeződésének változását elsősorban a Fox10, a Foxd3 és a Snaill/2 gének, illetve az általuk kódolt transzkripciós faktorok szabályozzák. A szöveteken keresztüli vándorlásra képes fenotípus kialakításának további előfeltétele a bazális membrán és az extracelluláris mátrix bontásához nélkülözhetetlen enzimek (a disintegrin and metalloproteinase - ADAM), fehérjék és mátrixmetalloproteázok megjelenése az NC-sejtek felszínén. A sejtek mozgásképességét pedig a citoszkeleton dinamikus átrendeződési képessége, elsősorban a globuláris aktin szálakká történő polimerizációja és az aktinfilamentumok membránhoz kötôdése biztosítja. Utóbbi két folyamat transzkripciós szabályozásáról elég keveset tudunk, de a Snaill/2, FoxD3 és Soxlo gének ebben is szerepet játszanak. Az EMT során kialakult, invázióra és migrációra képes NC-sejtekben kifejeződő gének alkotják az úgynevezett „ganglionléc-migrációs modult”. Ennek a múködését a legnehezebb vizsgálni, mivel a már 
A

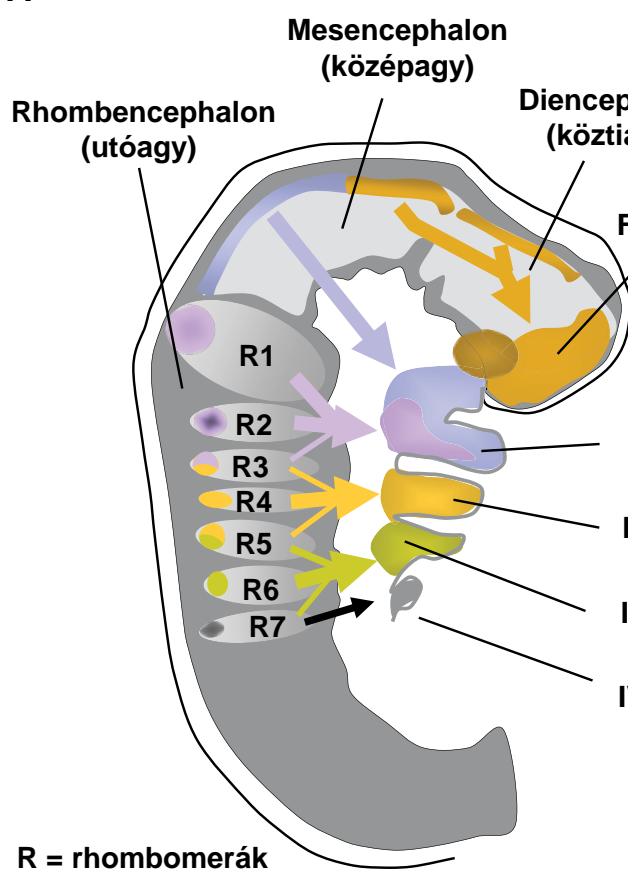

\section{Mandibularis ív \\ V. nervus trigeminus, nervus mandibularis}

Meckel-féle porc, maxilla, mandibula (egy része), os zygomaticum (járomcsont), malleus (kalapács), incus (üllö)

\section{Nyelvcsonti ív}

VII. nervus facialis

Reichert-féle porc, stapes (kengyel), os hyoideum (nyelvcsont kis szarva és testének felső része), processus styloideus, ligamentum stylohyoideum

\section{3. ív \\ IX. nervus glossopharyngeus \\ os hyoideum (nagy szarva és testének alsó része)}

\section{4-6. ívek}

$X$. nervus vagus, nervus laryngeus vándorló sejtek közül szinte lehetetlen akár csak többékevésbé homogén populációkat izolálni. Annyi azonban bizonyos, hogy számos, a specifikációs modulból már ismert gén (FoxD3, Snail2, Pax3/7 és Sox9/10) mellett a fejlódésnek ebben a szakaszában kezdenek fokozatosan kifejeződni azok a transzkripciós faktorok, amelyek egyegy meghatározott irányba terelik az érintett NC-sejtek differenciálódását (például: Phox2b, ideg- és gliasejt; Mitf, melanocyta), azaz biztosítják a ganglionlécsejtek diverzifikációját $[6,7]$.

\section{A ganglionlécsejtek vándorlása és differenciálódása}

A ganglionlécsejtek migrációja az embriogenezis során kollektív és irányított. A kollektivitás azt jelenti, hogy a sejtek csoportonként, összerendezetten vándorolnak, miközben folyamatos kölcsönhatásban vannak egymással, illetve az útjukat szegélyező, nem ganglionléc-eredetû sejtekkel. A migráció irányítottságán pedig azt értjük, hogy a különböző sejtcsoportok mindig szigorúan meg-

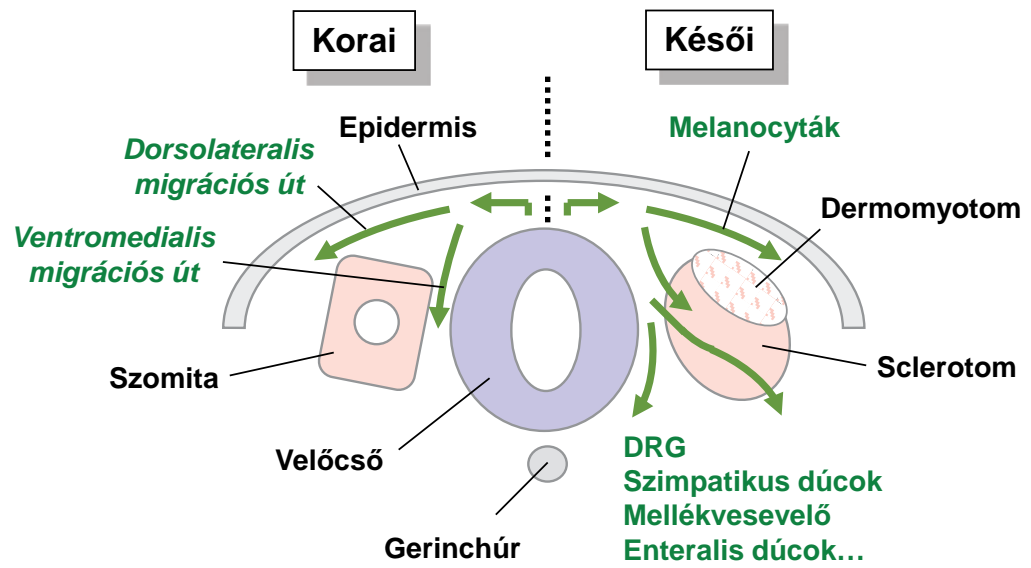


határozott útvonalakon mozognak, amíg el nem érik a célszervüket. A folyamat molekuláris szabályozása rendkívül bonyolult, számos pozitív és negatív jel integrációja határozza meg az egyes sejtcsoportok migrációs útvonalát, meghatározott anatómiai lokalizáció irányába történő vándorlásukat (homing) és beépülésüket a megfelelő szerv(ek)be. E jelátviteli utak részletes ismertetése meszsze meghaladná összefoglalónk kereteit, így csak röviden felsoroljuk a legfontosabbakat.

A sejt-sejt kölcsönhatások közül kiemelkedő jelentőségú a sejtek mozgásának kontakt gátlása (contact inhibition of locomotion - CIL), amihez szükség van az RhoA (Ras homolog gene family, member A), egy kis GTPáz aktiválására. Ez részben a Wnt/PCP (WNT/planar cell polarity signaling pathway) úton valósul meg, de az $\mathrm{N}$-cadherin is szerepet játszik benne. A különböző sejtfejlődési sorok elkülönülését (sorting) elsősorban az ephrinek és receptoraik (Eph) biztosítják. Az egyes, különböző utakat járó NC-sejt-csoportok tagjai eltérő ephrin/Eph mintázattal (kóddal) rendelkeznek, ami megakadályozza a keveredésüket, illetve kijelöli azt is, hogy milyen ephrin/Eph kóddal rendelkező, nem ganglionléc-eredetű sejtek közé tudnak behatolni. Az ephrin/ Eph rendszer múködését a plexin-neuropilin heterodimer receptorokhoz kötődő szemaforinok egészítik ki. A sejt-sejt kölcsönhatások révén kijelölt utakon vándorló NC-sejtek mozgását különböző kemokinek és kemotaktikus aktivitású citokinek, mint például a stromasejt-eredetü faktor 1 (SDF-1), a vascularis endothelialis növekedési faktor (VEGF), a vérlemezke-eredetű növekedési faktor (PDGF), a fibroblastnövekedési faktor-2 (FGF-2) és a gliaeredetü növekedési faktor (GDNF) segítik [8].

A legösszetettebb a feji NC-sejtek vándorlása. Kezdetben egyetlen folyamatos hullámban mozognak, ami azonban hamarosan több ágra bomlik, köztük pedig ganglionléc-eredetű sejtektől mentes régiók alakulnak ki. $\mathrm{Az}$ anterior-posterior tengely mentén haladva a köztiagy, a középagy és az utóagy magasságából kiinduló NCsejtek a 2. A ábrán nyilakkal jelzett migrációs utakon telepítik be a frontonasalis nyúlványt és az első négy garat- vagy kopoltyúívet. A frontonasalis nyúlványba a köztiagyból és a középagy anterior részéból vándorolnak NC-sejtek. Az első (mandibularis) garatívet jórészt a 2. rhombomerából (R2), kisebb részben pedig a középagy posterior részéből és az Rl-ből, valamint R3-ból származó ganglionléc-eredetű sejtek töltik fel. A második (nyelvcsonti) garatívben az R4-ból származó NC-sejtek dominálnak, kevés R3- és R5-eredetû sejttel keverve. Ugyancsak vegyes (R6 és R7) eredetüek a negyedik garatívbe vándorló ganglionlécsejtek. A posztmigrációs NC-sejtek hozzák létre - az egyes garatíveknek megfelelően - az V., a VII., a IX. és a X. agyidegek érződúcait, valamint az úgynevezett ectomesenchymát. Utóbbi alkotja a craniofacialis terület váz- és kötőszöveti elemeinek nagy részét. Azaz a feji NC-sejtek nemcsak gliasejtek, neuronok és melanocyták irányába képesek differenciálódni, hanem olyan sejtek létrehozására - adi- pocyta, chondrocyta, fibroblast, myofibroblast, osteocyta - is képesek, amelyek a test többi részén egyértelmúen mesodermalis eredetúk $[9,10]$. A legfontosabb, ganglionléc-eredetû́ craniofacialis vázelemeket a 2. B ábrán tüntettük fel. (A fej és a nyak izomzata ugyanakkor mesodermalis eredetú.) A Sox $10^{+} \operatorname{Sox} 9^{-}$cranialis NC-össejtek ectomesenchyma irányú elköteleződésének kulcslépése a Sox9 gén kifejeződése és a Soxl0 csendesítése. Az ilyen, elsősorban transzformáló növekedési faktor- $\beta$ I (TGF- $\beta 1$ ) hatására létrejövő Sox10-Sox $9^{+}$mesenchymalis ős- vagy elődsejtekből (MSC) már csak kötő-, porc- vagy csontszövet jöhet létre. Ugyanakkor a továbbra is $\operatorname{Sox}_{10^{+}} \operatorname{Sox}^{-}$ NC-őssejtek, fibroblastnövekedési faktor-8 (FGF-8) jelenlétében, ideg- és gliasejtekké differenciálódnak [11].

A ganglionléc törzsi szakaszából kilépő NC-sejtek két útvonalon juthatnak el az embrió különböző szerveibe (3. ábra). A dorsolateralis úton migráló NC-sejtekből, miután elérték végleges „rendeltetési” helyüket, melanocyták lesznek. A DRG-ket, a szimpatikus és az enteralis dúcokat vagy például a mellékvesevelő kromaffin sejtjeit viszont a ventromedialis úton migráló NC-sejtek hozzák létre. Ez az út a korai embrióban a szomiták és a velőcső fala között vezet, később azonban - a szomiták érésével párhuzamosan - a sejtek egyre inkább a sclerotomon keresztül vándorolnak. A legnagyobb különbség a feji és a törzsi NC-sejtek között az, hogy utóbbiakból - legalábbis jelenlegi tudásunk szerint - in vivo soha nem keletkezik ectomesenchyma, pontosabban porc vagy csont. Endoneuralis fibroblastokká és melanocytákká azonban képesek differenciálódni. Utóbbiakról viszont nem tudjuk, hogy azonosak-e a dorsolateralis úton migráló NC-sejtekből fejlődő és a szervezetben található pigmentsejtek döntő többségét kitevő melanocytákkal (l. még később!) [4, 12].

\section{Ganglionlécőssejtek}

A ganglionlécőssejt (neural crest stem cells - NCSC) kifejezést Stemple és Anderson vezették be [13]. Több munkacsoport is igazolta ugyanis, hogy ezek a rágcsálók ganglionlécéből áramlási citométer segítségével izolált, az idegi eredetû növekedési faktor (nerve growth factor - NGF) kis affinitású receptorának egyik láncát (p75) hordozó sejtek, számos sejtfejlődési sor - ideg- és gliasejt, melanocyta, myofibroblast, chondrocyta és osteocyta - irányába is képesek differenciálódni [14]. In vitro kultúrában erre az NC feji és törzsi szakaszából származó ganglionlécsejtek egyaránt képesek. Felvetődött tehát, hogy in vivo csak az aktuális szöveti környezet gátolja a törzsi NC-sejtek ectomesenchymalis irányú fejlődését. A ganglionléc- és NC-sejt-kimérákkal (fürj-csirke, egér vagy patkány-csirke) végzett kísérletek azonban részben ellentmondó eredményre vezettek. Bár az ektopikus helyekre beültetett ganglionlécszakaszok vagy szeparált NC-sejtek általában multipotensnek bizonyultak, differenciálódási képességük még azonos szöveti környezetben sem volt mindig azonos. Patkányembrió béltraktu- 
sából izolált NC-sejtek csirkeembrióba ültetve például elsősorban idegsejtekké, míg felnőtt donorból származó társaik inkább gliasejtekké differenciálódtak. A rágcsálók foetalis ülőidegéből (nervus ischiadicus) izolált NC-sejtek csirkeembrióba ültetve fóként gliasejtek, a foetalis béltraktus területéról származók viszont inkább idegsejtek irányába fejlődtek. A fiatalabb embrióból nyert NCsejtek másik embrióba ültetve messzebb vándoroltak, mint az idősebb embrióból származó társaik. Eszerint tehát a különböző korú és különböző anatómiai lokalizációjú NC-sejtek között vannak különbségek, és a posztmigrációs ganglionlécsejtek öregedése is megfigyelhető. Így nem meglepő, hogy a kutatók között éles vita bontakozott ki arról, mikor válnak az NC-sejtek elkötelezetté a különböző sejtfejlődési sorok irányába. Talán a premigrációs fázisban? Sorsuk már vándorlásuk megkezdése előtt, a ganglionlécben eldőlne? Vagy valamikor a migráció során köteleződnek el? Netán amikor elérték végleges anatómiai lokalizációjukat? Más szóval: meddig őrzik meg multipotenciájukat? De az is felvetődött, hogy a ganglionléc részben multipotens NCSC-ból, részben már elkötelezett elődsejtekből áll [2, 15].

Hatalmas előrelépést jelentett, amikor a különbözó transzgenikus (knock-in) és génkiütéses (knock-out) technikák elterjedése lehetővé tette a pre- és posztmigrációs NC-sejteknek a korábbiaknál jóval homogénebb sejtpopulációk formájában történő izolálását és karakterizálását, valamint az egyes sejtfejlődési sorok in vivo követését (lineage tracing). Különösen a bacteriophag eredetű Cre/loxP rekombinációs rendszer, illetve ennek indukálható (kondicionált) változata bizonyult hasznosnak. A Cre enzim egy DNS-rekombináz (pontosabban egy l-es típusú topoizomeráz), amely a loxP nukleotidszekvenciát ismeri fel, és kivágja a DNS-ből azokat a géneket, amelyeket két loxP szekvencia határol. Az ezen az elven múködő rekombinációs rendszer segítségével tulajdonképpen bármely gén célzottan eltávolítható a genomból. Ha a Cre gén kifejeződését szövetspecifikus promoter szabályozza, a génkiesés csak a megcélzott szövetet érinti. Amennyiben ez a promoter még indukálható is - például ösztrogénreceptort (ER) tartalmaz - a Cre enzim kifejeződése bármikor indukálható egy tamoxifeninjekcióval. A premigrációs NC-sejtek vizsgálatára a Wntl-CreER ${ }^{\mathrm{T}}$ [16], míg a posztmigrációs ganglionlécsejtek sorsának a követésére a Sox10-CreER ${ }^{\mathrm{T}}$ [17] génkonstrukciók, valamint egy megfelelő, úgynevezett riporter locust hordozó transzgenikus egér hibridjei a legalkalmasabbak. A riporter locus $(R 26 R=$ Rosa26 reporter) a $\beta$-galaktozidáz enzim vagy egy fluoreszcens fehérje génjét tartalmazza, ami elé egy loxP-szekvenciák közé foglalt (floxolt) stopkodont illesztenek [18]. Így vemhes $W n t 1-C r e E R^{\mathrm{T}} ; \quad R 26 R$ vagy Sox10-CreER ${ }^{\mathrm{T}}$; $R 26 R$ nőstény egereket tamoxifennel oltva a premigrációs $\left(W n t 1^{+}\right)$, illetve a már vándorló $\left(\right.$Sox $\left.10^{+}\right)$NC-sejtekben kifejeződik a Cre enzim, kivágja a riporter gén expresszióját blokkoló stopkodont, és ezzel lehetővé teszi a $\beta$-galaktozidáz enzim vagy a fluoreszcens fehérje kifeje- ződését (4. ábra). Gyakran használt még a P0 promoter is. A P0 (protein 0) myelinfehérje ugyan a Schwann-sejtekre jellemző, de az embrionális NC-sejtekben is kifejeződik. Ezt a rendszert fejlesztették tovább Arianna Baggiolini és mtsai [19], akik Wntl-CreER ${ }^{\mathrm{T}}$; R26R Confetti és Sox10-CreER ${ }^{\mathrm{T} 2}$; R26R Confetti homozigóta nőstény egereket oltottak vemhességük 9. napján $(\mathrm{E} 9,0)$ tamoxifennel, majd két és fél nappal később $(\mathrm{E} 10,5)$ vizsgálták a különböző színben fluoreszkáló, pre- és posztmigrációs NC-sejtek, illetve leszármazottaik anatómiai lokalizációját és differenciálódási markereit. Az R26R Confetti transzgenikus egér egy stopkodonból, négy különböző színű fluoreszcens fehérjét kódoló génből, valamint loxP-szekvenciákból álló - Brainbow-2.1-nek nevezett összetett riportergén-komplexet hordoz (5 A ábra). A négy fehérje az nGFP (sejtmag-lokalizációs szekvenciát is hordozó zöld fluoreszcens fehérje - green fluorescent protein), az YFP (sárga fluoreszcens fehérje - yellow fluorescent protein), az RFP (vörös fluoreszcens fehérje - red fluorescent protein) és az mCFP (kék színú fluoreszcens fehérje - cyan fluorescent protein). Mint az 5 $A$ ábra mutatja, a stopkodont és a fehérjéket kódoló DNS-szakaszokat egyaránt loxP szekvenciák fogják közre. Ráadásul, mind a fehérjekódoló, mind a loxP szekvenciák részben változó, $5^{\prime}-3^{\prime}$, illetve $3^{\prime}-5^{\prime}$ pozícióban vannak beépítve a komplexbe. Így, amikor a Cre enzim aktiválódik a Brainbow-2.1-et hordozó sejtekben, a stopkodon eltávolításával egy időben sajátos átrendeződési folyamat(ok) indul(nak) meg a fluoreszcens fehérjéket kódoló gének között is. Az 5 A ábrán jelölt loxP szekvenciák között inverziók, deléciók, végül újabb inverziók történnek, aminek következtében minden érintett sejtben csak egyetlen, megfelelő pozícióba került fluoreszcens fehérje expresszálódik. Vagyis piros, kék, zöld vagy sárga színben fluoreszkáló sejtek jönnek létre, amiknek az utódsejtjei is öröklik ezt a tulajdonságot, és bárhova vándoroljanak is az embrióban, az eredeti - szülői - sejtnek megfelelő színben fognak világítani a mikroszkópban. Ráadásul, ha az R26R Confetti egér homozigóta, azaz genomja két azonos Brainbow-2.1-es locust tartalmaz, akkor a Cre enzim által kiváltott, véletlenszerú génátrendeződés mindkét locuson bekövetkezik. Így az érintett sejtekben összesen 10 különböző színkombináció valamelyike jöhet létre ( $5 B$ ábra), vagyis a rendszer tízféle sejt(populáció) sorsának egyidejü követésére alkalmas. Baggiolini és munkatársai így tudták igazolni, hogy mind a Wnt1-CreER ${ }^{\mathrm{T}}$; R26R Confetti egerekben megfigyelhető premigrációs, mind a Sox10-CreER $R^{\mathrm{T} 2}$; $R 26 R$ Confetti egerekben vizsgálható, posztmigrációs NC-sejtek multipotensek in vivo (is). Adott színkombinációval jellemezhető törzsi NC-sejtek utódsejtjei között egyaránt találtak idegsejteket (a DRG-ben és a szimpatikus dúcokban), Schwann-sejteket és melanocytákat. A ganglionlécőssejtek terminális differenciálódásának irányát tehát, a jelek szerint, elsősorban végleges anatómiai lokalizációjuk, pontosabban az ott található szöveti mikrokörnyezet határozza meg in vivo. (Azt természete- 


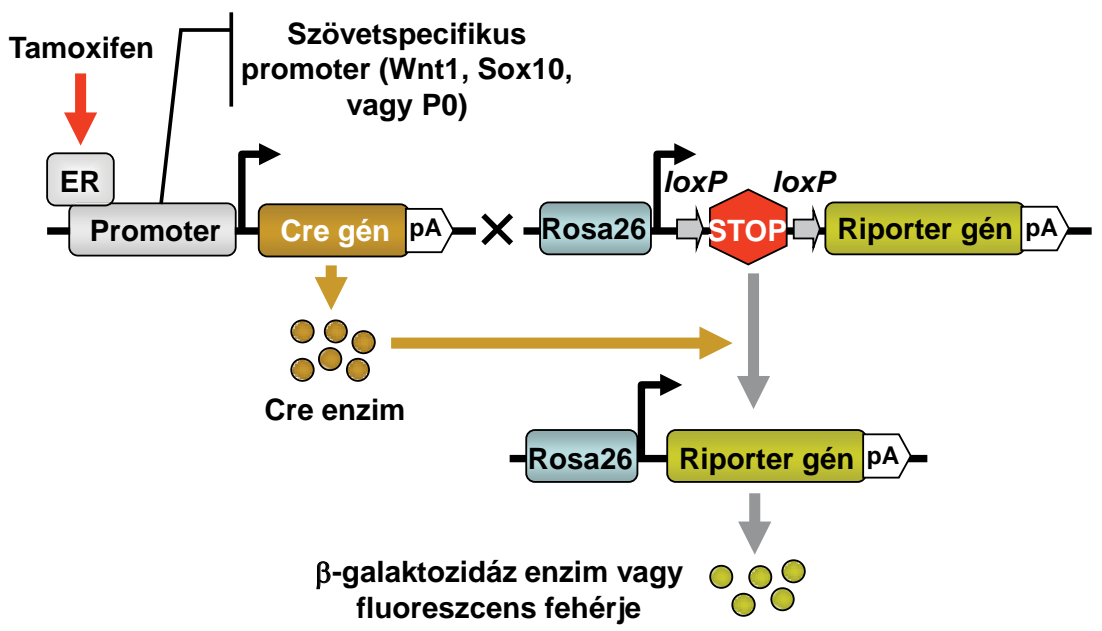

A

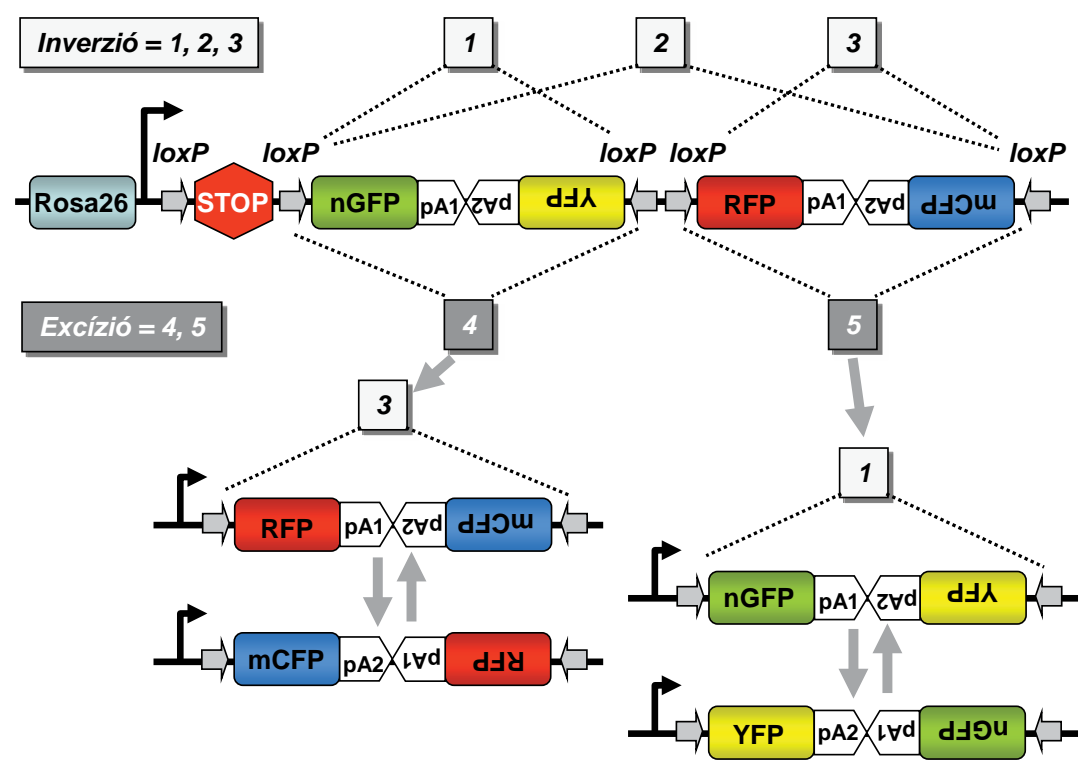

B

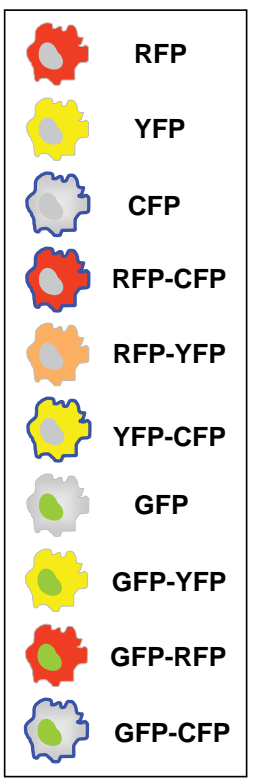

5. ábra

| Az R26R Confetti (Brainbow-2.1) locus átrendeződése aktív Cre rekombináz enzim jelenlétében

sen ennek a kísérletnek az alapján sem lehet kizárni, hogy az NCSC-k mellett elkötelezett sejtek is találhatók a ganglionlécben.)

\section{Ganglionléc-eredetü multipotens szöveti őssejtek}

A génmanipulációs technikákon alapuló sejtfejlődésisorkövetési módszerek alkalmazása tette lehetővé azt is, hogy igazolják számos, a felnőtt szervezetben megtalálható szöveti őssejtpopuláció ganglionléc-eredetét. Ez korábban sok nehézségbe ütközött, mivel számos ilyen őssejt nem fejez ki egyértelmüen az NC-hez köthető markereket, mint amilyen például a p75. Az 1. táblázat- ban ezek közül a felsorolt ganglionléc-eredetû szöveti őssejtek közül mutatunk be néhányat részletesebben $[20,21,22]$. Az első, egérbőrből izolált NC-eredetú szöveti őssejtek az úgynevezett bőreredetü prekurzor sejtek (skin-derived precursor cells - SKP) voltak [23]. Kisebb, lebegő sejtcsomók (szférák) formájában hosszú ideig fenntarthatók in vitro kultúrában, azaz önfenntartók. Megfelelő induktorok jelenlétében neuronok, gliasejtek, adipocyták, melanocyták és simaizomsejtek irányába képesek differenciálódni, tehát multipotensek. Wntl-Cre; R26R kettős transzgenikus egerekkel végzett sejtfejlődésisor-követési vizsgálatok igazolták, hogy a $\beta$-galaktozidáz enzimet kifejező SKP-sejtek jó része a bajuszszálak tüszőiben, a dermalis papillákban található. A csirkeembrióba oltott egér-SKP-sejtek követik az en- 
1. táblázat

| Ganglionléc-eredetú szöveti őssejtek

\begin{tabular}{|c|c|}
\hline Sejttípus & Markerek \\
\hline SKP (skin-derived progenitor) & $\begin{array}{l}\text { Nestin, Snail, Slug, Twist, Sox9, } \\
\text { Oct } 4 \text {, Nanog }\end{array}$ \\
\hline $\begin{array}{l}\text { EpiNSC (epidermal neural crest } \\
\text { stem cell) }\end{array}$ & $\begin{array}{l}\text { Nestin, Sox 10, Lin } 28, \text { Oct } 4 \text {, } \\
\text { Nanog, Klf4, Sox } 2 \text {, c-Myc }\end{array}$ \\
\hline $\begin{array}{l}\text { PNSC (palatal neural crest- } \\
\text { derived stem cell) }\end{array}$ & $\begin{array}{l}\text { Nestin, p75, Sox } 9 \text {, Notch1, } \\
\text { Slug, Snail, Sox } 2 \text {, Klf4, Oct } 4 \text {, } \\
\text { c-Myc }\end{array}$ \\
\hline $\begin{array}{l}\text { HOMSCs (human oral mucosa } \\
\text { stem cell) }\end{array}$ & $\begin{array}{l}\text { Nestin, p } 75 \text {, SSEA } 4 \text {, Oct } 4, \\
\text { Sox } 2 \text {, Nanog, Tra-2-54, Tra-49, } \\
\text { ALP }\end{array}$ \\
\hline $\begin{array}{l}\text { PDLSC (periodontal ligament } \\
\text { stem cell) }\end{array}$ & $\begin{array}{l}\text { Nestin, STRO-1, Slug, Twist, } \\
\text { Sox9, ABCG2 és SSEA-1, p75, } \\
\text { NHK-1, Oct } 4 \text {, Sox } 2 \text {, Nanog, } \\
\text { Klf4, SSEA-1, SSEA-3, SSEA-4, } \\
\text { TRA-1-60, TRA-1-81 }\end{array}$ \\
\hline $\begin{array}{l}\text { DPSC (dental pulp stem cell); } \\
\text { SHED (stem cells derived } \\
\text { from exfoliated human } \\
\text { deciduous teeth) }\end{array}$ & $\begin{array}{l}\text { Nestin, p75, Oct } 4 \text {, Sox } 2 \text {, } \\
\text { Nanog, Rex1 }\end{array}$ \\
\hline $\begin{array}{l}\text { OE-MSC (olfactory mucosa } \\
\text { mesenchymal stem cell) }\end{array}$ & Nestin, CD54, CD90, Sox9 \\
\hline $\begin{array}{l}\text { Nm-MSC (nasal mucosa } \\
\text { mesenchymal stem cell) }\end{array}$ & $\begin{array}{l}\text { CD90, CD } 54, \text { CD29, CD } 44, \\
\text { CD73, CD105 }\end{array}$ \\
\hline COP (corneal precursor) & $\begin{array}{l}\text { Nestin, Musashi-1, Notchl, } \\
\text { Scal, Sox9, Twist, Slug, Snail }\end{array}$ \\
\hline MCC (murine corneal cells) & $\begin{array}{l}\text { Nestin, Sox } 9 \text {, Snail, Slug, Twist, } \\
\text { Musashi-1, vimentin }\end{array}$ \\
\hline Carotiscsomó NCSC & $\mathrm{GFAP}^{+},\left(\mathrm{p} 75^{-}\right)$ \\
\hline $\begin{array}{l}\text { Szív NCSC } \\
(\mathrm{SP}=\text { side population })\end{array}$ & $\begin{array}{l}\text { Nestin, Musashi-1, CD29, } \\
\text { CD } 44\end{array}$ \\
\hline Ülőideg (nervus ischiadicus) & $\mathrm{P} 75, \alpha 4,\left(\mathrm{P} 0^{-}\right)$ \\
\hline DRG & $\begin{array}{l}\text { Nestin, Musashi-1, p75, Sox } 10 \text {, } \\
\text { P0 }\end{array}$ \\
\hline Csontvelő & $\begin{array}{l}\text { Nestin, p75, Sox 10, Slug, Snail, } \\
\text { PDGFRa }^{+}\end{array}$ \\
\hline
\end{tabular}

dogén NC-sejtek migrációs útvonalait, majd ideg- és gliasejtekké differenciálódnak [24]. Az állatok hátbőréből izolált SKP-sejtek eredete azonban vitatott, valószínúleg nem a ganglionlécből, hanem a mesodermából származnak, annak ellenére, hogy plaszticitásuk az SKPsejtekéhez hasonló [25]. A bajuszszőrtüszők úgynevezett „bulge” (kidudorodás) régiójából izolált másik multipotens szöveti őssejt, az epidermalis ganglionlécőssejt (epidermal neural crest stem cell - epi-NCSC) az SKPsejtekhez hasonlóan önfenntartó és multipotens in vitro. Ganglionléc-eredetüket és migrációs képességüket Wntl-Cre; R26R egereken is igazolták. Gerincsérülés területére oltva azonban - meglepő módon - nem differenciálódnak Schwann-sejtekké, hanem inkább GABAerg neuronokat és oligodendrocytákat hoznak létre [26]. Különböző, dermalis eredetû multipotens őssejteket az emberi bőrből (elsősorban előbőrből) is izoláltak, de ezeknek a sejteknek a viszonylag jól karakterizált egérőssejt-populációkkal való azonossága meglehetôsen bizonytalan [27].

A patkány és az ember szájpadlásából egyaránt izolálható, in vitro sejttenyészetekben szférák formájában növekedő, úgynevezett szájpadi ganglionléc-eredetű őssejtek (palatal neural crest-related stem cells - pNC-SC) sorozatosan átolthatók (önfenntartók), és többmagvú myotubulusokká, $\mathrm{TuJl}^{+}$idegsejtekké, valamint $\mathrm{GFAP}^{+}$ gliasejtekké képesek differenciálódni (multipotensek) [28]. A fogakban található különböző szöveti őssejtet (6. ábra) - fogbél- (pulpa-) őssejtek (dental pulp stem cells - DPSC), a tejfogak pulpájából származó őssejtek (stem cells from human exfoliated deciduous teeth SHED), gyökérhártyaőssejtek (periodontal ligament-derived stem cells - PDLSC), apicalis papillaőssejtek (stem cells from apical papilla - SCAP) a legtöbbet vizsgált NC-eredetû emberi őssejtek. (A fogaknak csak a zománca és a pulpában található erek nem ganglionléc-eredetüek.) In vitro kultúrában a tenyésztóedény falához tapadva növekednek (adherensek), fibroblastszerú morfológiát mutatnak, és elsősorban adipocyta, chondrocyta, valamint osteoblast irányba képesek differenciálódni, de megfelelő induktorok jelenlétében - ideg- és gliasejtek is keletkezhetnek belőlük. Tulajdonságaik tehát szinte azonosak a más anatómiai területekról származó - csontvelői, zsírszövet-eredetû stb. -, de egyértelmúen mesodermalis eredetü, úgynevezett mesenchymalis ős- vagy stromasejtekével (MSC). Így egyértelmúen az ectomesenchyma MSC-inek tekinthetők [29]. Szintén a craniofacialis területről származnak a szaruhártya (cornea) prekurzor sejtjei (cornea-derived precursors - COP), a keratinocyták és a cornea endothelsejtjeinek az ôs- vagy elődsejtjei. NC-eredetüket P0- és Wntl-Cre, valamint riportergén-konstrukciót hordozó, kettős transzgenikus, felnőtt egerekben is igazolták. In vitro kultúrában szférák formájában növekednek, többször passzálhatók, és keratinocytákká, endothelsejtekké, fibroblastokká, myofibroblastokká, adipocytákká, valamint chondrocytákká differenciáltathatók [30]. Sejttenyészetben ugyancsak szférák formájában tarthatók fenn a carotiscsomóból (glomus caroticum) izolált, $\mathrm{GFAP}^{+}$, NC-eredetű sejtek. Multipotensek, elsősorban dopamintermelő idegsejtekké és $\alpha$-simaizom-aktin-pozitív sejtekké képesek alakulni [31]. Az újszülött és felnőtt egerek szívéból izolált, sejttenyészetben szférákat képző NCSC-k átfedést mutatnak a szívből Hoechst-festék-kipumpálási képességük alapján azonosított, úgynevezett SP (side population) sejtekkel, ami önmagában is szöveti ôs-, illetve elődsejt jellegükre utal. In vitro ideg- és gliasejtek, melanocyták, chondrocyták és myofibroblastok irányába differenciáltathatók. In vivo, csirkeembrióba oltva, az endogén NC-sejtekhez hasonlóan vándorolnak, a szív és a perifériás idegrendszer megfelelő struktúráinak a kialakításában vesznek részt [32]. Az ülőideg (nervus ischiadicus) és hátsó gyökérdúcok területéról származó, többé-kevésbé multipotens sejtek esetében azonban felmerült, hogy ezek való- 


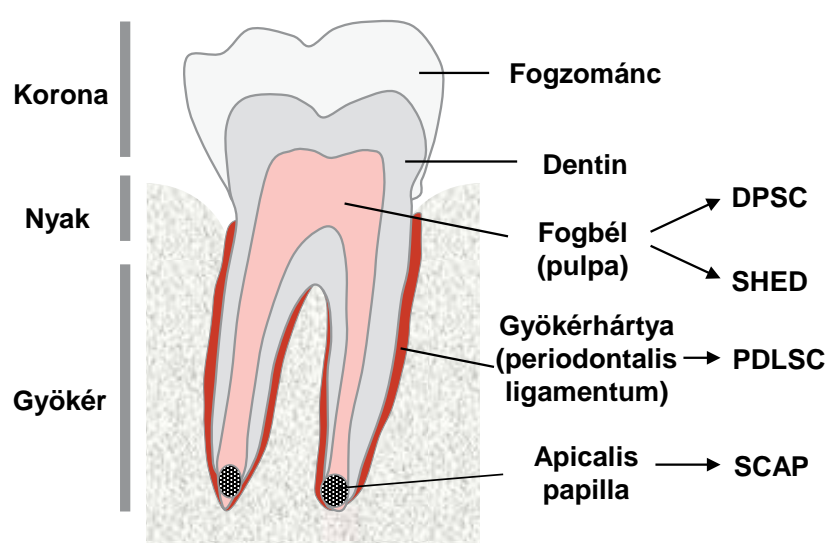

6. ábra

A fogakban található, ganglionléc-eredetú, ectomesenchymalis őssejtek

jában dedifferenciálódott gliasejtek (Schwann-sejtek; 1. a következő részben!).

Sajátos a helyzet a csontvelő stromaállományát, azon belül is a vérképző őssejtek mikrokörnyezetét (niche) kialakító MSC-k esetében. Mint már említettük, a különböző anatómiai lokalizációban található MSC-ket, a craniofacialis terület kivételével, mesodermalis eredetûnek tartják. Ugyanakkor Takashima és mukatársai már 2007-ben felvetették [33], hogy az MSC-k legkorábbi, az egyedfejlődés során először megjelenő hulláma teljes egészében ganglionléc-eredetû́ sejtekből áll. Helyüket azonban - a craniofacialis régió kivételével - még az embriogenezis korai szakaszában mesodermalis eredetû MSC-k veszik át. A legújabb eredmények viszont azt mutatják, hogy NC-eredetû́ csontvelői MSC-k születésünk után is előfordulnak a vörös csontvelőben. Mi több, ezek a nestin és PDGF receptor-alfa-pozitív MSC-k meghatározó szerepet játszanak a vérképző őssejt niche kialakításában. Ugvanakkor nestinnegatív. mesodermalis eredetú társaik inkább a porc és csontszövet létrehozásáért felelősek in vivo [34]. (Meg kell jegyezni, hogy a nestin $^{+}$és nestin ${ }^{-}$MSC-k in vitro - elsósorban adipocyta, chondrocyta és osteoblast irányú - differenciálódási képessége nem különbözik számottevően [35].)

\section{Schwann-sejtek és melanocyták}

A myelináló és nem myelináló (Remak) Schwann-sejtek, valamint a melanocyták egyaránt ganglionléc-eredetűek. A ventromedialis úton vándorló NCSC-kbő́l kialakuló multipotens Schwann-sejt-prekurzorok (Schwann cell precursor - SCP) - a gliasejtek mellett - endoneuralis fibroblastok, paraszimpatikus idegsejtek és melanoblastok irányába is képesek differenciálódni az embrióban (7. ábra). Az axonokon kifejeződő, III-as típusú neuregulin l-et (NRG1) ErbB2/ErbB3 (epidermalis növekedési faktor receptor) receptoraik révén ismerik fel. $\mathrm{Ez}$ a kölcsönhatás nélkülözhetetlen túlélési jelzés az SCP-k számára, hiányában gyorsan apoptotizálnak a sejtek. Az NGRI-ErbB2/ErbB3 kölcsönhatás egyben gátolja a neurogenezist és segíti a gliogenezist. A Notch-szignál szintén hozzájárul az SCP-k gliasejt irányú elköteleződéséhez (az axonokon számos Notch-ligandum található), mivel fokozza az ErbB3 gén kifejeződését, és ezzel növeli az NRGl-szignál hatékonyságát. Az éretlen Schwannsejtek már részben autokrinek, in vitro kultúrában IGF-2-t, neutrophin-3-at, PDGF-et, LIF-et és lizofoszfatidsavat termelnek, ami átmenetileg biztosítja a túlélésüket. (Axonfüggésük azonban nem szúnik meg teljesen, ha hosszabb ideig nem kerülnek kapcsolatba idegsejtekkel, elpusztulnak.) A perifériás idegek sérülésekor a Schwann-sejtek dedifferenciálódnak. A kialakuló, úgynevezett regeneráló Schwann-sejtek (Büngner-sejtek) bipoláris morfológiát vesznek fel, demyelinálódnak és osztódni kezdenek. Reaktiválódnak bennük az éretlen

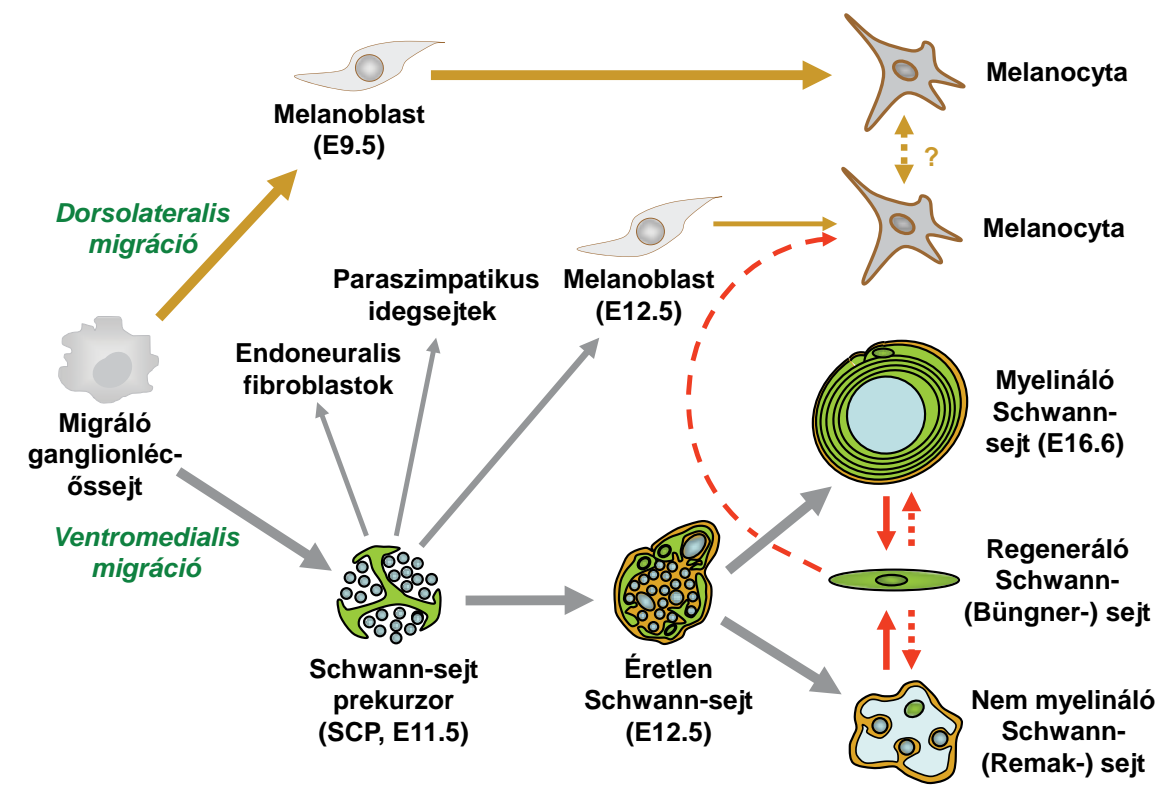


Schwann-sejtekre, sőt részben az SCP-kre jellemző gének, míg a myelinisatióhoz kapcsolódó gének kifejeződése csökken. Neutrofikus (BDNF, GDNF, NGF, VEGF stb.), a sérült axonok túlélését és növekedését segítő faktorokat, valamint gyulladáskeltő cito- és kemokineket (TNF- $\alpha$, LIF, IL-1, IL-6, és MCP-1) termelnek, amik macrophagokat vonzanak a területre. A macrophagok - amellett, hogy eltakarítják a károsodott sejt- és szövetmaradványokat - további citokineket termelnek, ezzel elősegítik a revascularisatiót, de például az IL-6 és a LIF közvetlenül is hozzájárul az axonok regenerációjához. Ráadásul, a Büngner-sejtek nemcsak Schwann-sejtek, hanem melanocyták irányába is képesek differenciálódni, ezért a regeneráció helyén sokszor elszíneződés(ek) figyelhető(k) meg. A Schwann-sejtek fenotípusa tehát a felnőtt szervezetben sem mindig stabil $[36,37]$.

A különböző gerincesekben a szem, a bőr, a haj, a szőr, a tollak és a pikkelyek színét melanintermelő sejtek, a melanocyták adják. Elődsejtjeik, az NCSC-kből keletkező melanoblastok szinte mindenhol megtalálhatók az embrióban. Eredetük kettős: a dorsolateralis vagy a ventromedialis útvonalról is származhatnak. A dorsolateralis úton, a dermisben vándorló ganglionlécsejtek egy önfenntartó szöveti őssejt-populációt (melanocyte stem cells - MeSC) hoznak létre, amely tartósan képes pótolni a pusztuló pigmentsejteket. Az őszülés ennek az őssejtpopulációnak a kimerülését jelzi. A ventromedialis útvonalon vándorló, multipotens NC-sejtek egy részéből keletkező SCP-k a Schwann-sejtek és a melanocyták bipotens elődsejtjei (1. fent!). Nem tudjuk biztosan, hogy a belőlük keletkező pigmentsejtek valóban azonosak-e a dorsolateralisan vándorló NC-sejtekből származó melanocytákkal vagy van-e valami génexpressziós, netán funkcionális különbség közöttük. Az MeSC-kből származó melanoblastok egérben az E15,5-re telepítik be az epidermist és a szőrtüszőket, majd egy nap múlva $($ E16,5) a melanintermelés is megindul a sejtekben. Az újszülött állatokban még vannak follicularis és interfollicularis melanoblastok is, de később a szőrös bőrból eltünnek a pigmentsejtek prekurzorai. Emberben ezek az interfollicularis melanoblastok maradandók, és leánysejtjeik melanint termelnek. Felnőttkorban a melanocytavonal bőrben és szőrtüszőkben található tartalék sejtjeinek (MeSC) száma nagyjából állandó. A szőrtüszők ciklusai során mindig néhány melanoblast differenciálódik és biztosítja a pigmentációt, a többiek azonban a „bulge" (kidudorodás) régióban maradnak, csökken bennük a Mitf gén kifejeződése és nyugalomban lévő MeSC-ként várják a következő ciklus kezdetét. A melanocytafejlődési vonal iniciációjának mester transzkripciós faktora a Mitf (microphthalmia-associated transcription factor). A Mitf-hiányos egerekből hiányoznak a melanocyták, emberben pedig - legalábbis a betegek egy részében - a MITF gén csíravonalbeli mutációja felelős a Waardenburg-szindróma kialakulásáért. A Mitf expreszsziójának legfontosabb előfeltétele a migráló multipotens NC-sejtekben és az ideg/glia sejt irányba fejlődő
NC-eredetű sejtekben még kifejeződő FoxD3 és a Sox2 gének gátlása. A FoxD3-ケ, kondicionált génkiütött egerekben a fejlődő idegeket Mitf $^{+}$sejtek veszik körül, bennük tehát a gliasejtek helyett melanocyták keletkeznek. Ugyanakkor a Sox2 fokozott kifejeződése következtében a pigmentsejtek túnnek el az állatokból. A gliasejt, illetve melanocytasejt-fejlődési sorok tehát viszonylag könnyen átjárhatók [38, 39].

\section{Összefoglalás és kitekintés - a negyedik csíralemez}

Összefoglalásként tehát elmondhatjuk, hogy a ganglionlécőssejtek számos sajátsága eltér a tipikus, multipotens szöveti őssejtekétől, mint amilyenek például a vérképző vagy a mesodermalis eredetû mesenchymalis őssejtek.

- Egyedülálló inváziós és migrációs képességgel, valamint a szöveti őssejtekénél jóval szélesebb fejlődési potenciállal rendelkeznek.

- Az érett testi sejtek - neuronok és gliasejtek, adipo-, osteo- és chondrocyták, odontoblastok, fibroblastok, neuroendokrin és pigmentsejek - mellett maguk is több, egész életünk során múködőképes szöveti őssejt-populációt hoznak létre.

- Plaszticitásukat még az embriogenezis viszonylag késői szakaszában is megőrzik (posztmigrációs NC-sejtek), amikor a környezetükben található többi sejt már egyértelműen elkötelezett valamilyen sejtfejlődési sor irányába.

- Az NCSC-eredetú érett testi sejtek sem teljesen stabilak, képesek dedifferenciálódni, majd egy másik, a kiindulási sejtekétől eltérő fenotípusú és funkciójú sejtpopulációt létrehozni, ahogy ezt a glia- (Schwann-) sejtek és a melanocyták példáján bemutattuk.

Ugyanakkor azt sem lehet kijelenteni, hogy az NCSC-k teljes egészében megőrizték volna a pluripotens, embrionális őssejtek fejlődési potenciálját. Még akkor sem, ha néhány génexpressziós vizsgálat eredményei esetleg erre (is) utal(hat)nak. Buitrago-Delgado és mtsai [40] szerint például a Xenopus blastula animális pólusán található, valamint az állatok ganglionlécéból izolált sejtek génexpressziós mintázata szinte azonos. Mivel a béka egyedfejlődése során a blastula animális pólusán található sejtek felelnek meg az emberi és az egérblastocysta belső sejtmasszájából származó pluripotens (embrionális) őssejteknek, a szerzők feltételezik, hogy a béka-NCSC-k valójában nem is multi-, hanem pluripotens őssejtek. Mások szerint az emberi NCSC-kben is kifejeződik az embrionális őssejtek pluripotenciáját biztosító génprogram három legfontosabb eleme, a POU5F1, a NANOG és a $S O X 2$ gén [41]. De a ganglionléc-specifikációs modulból megismert FoxD3-ról [42] és Snaill-ről [43] is kiderült, hogy hozzájárulnak a pluripotencia fenntartásához egér embrionális őssejtekben. Hangsúlyozni kell azonban, hogy bár a ganglionléc kialakulását, az NC-sejtek specifikációját és migrációját meghatározó génháló- 
zatok meglehetősen konzerválódtak a gerincesek evolúciója során [44], így a békákban és az emlősökben is hasonlóak, még a béka-NCSC-k sem differenciálódnak endodermalis irányba in vivo. A pluripotencia definíciójának alapja pedig éppen a mindhárom csíralemez irányába történő differenciálódási képesség. Vagyis az NCSC-k valóban egy sajátos, mind az embrionális (pluripotens), mind a „klasszikus” szöveti (multipotens) össejtektől különböző, a pluripotenciát biztosító genetikai program elemeit valamilyen szinten kifejező, de funkcionálisan mégsem egészen pluripotens őssejt-populációt alkotnak az embrióban. Így a ganglionlécet - Brian K. Hall nyomán [45] - joggal nevezhetjük negyedik csíralemeznek.

Az NCSC-k és a belőlük származó sejtek orvosi jelentőségét - a bevezetőben említett betegségek jobb megismerése mellett - elsősorban sejtterápiás alkalmazásuk ad(hat)ja. Főként az idegrendszer (például gerincvelő) vagy az érzékszervek (szem, fül) sérülése esetén van remény arra, hogy jobb terápiás eredmények érhetők el velük, mint amiket a jelenleg folyó - elsősorban vérképző és mesodermalis eredetü mesenchymalis őssejtek alkalmazásán alapuló - klinikai próbálkozások során megfigyeltek $[46,47]$.

\section{Anyagi támogatás: A cikk megírása anyagi támogatásban} nem részesült.

Szerzői munkamegosztás: K. Gy.: Anyaggyüjtés (irodalmazás), az ábrák anyagának összeállítása és a kézirat megfogalmazása. M. Zs.: Anyaggyưjtés (irodalmazás) és a kézirat megfogalmazása. K. T.: Anyaggyưjtés (irodalmazás). U. S. V.: Témavezetés, a kézirat végső formába öntése. U. F.: Témavezetés, az ábrák és a kézirat végső formába öntése. A cikk végleges változatát valamennyi szerző elolvasta és jóváhagyta.

Érdekeltségek: A szerzőknek nincsenek érdekeltségeik.

\section{Irodalom}

[1] Sell, S. (ed.): Stem cells handbook. 2nd ed. Humana Press, Springer, New York, 2013.

[2] Sperber, G. H.: Neural crest cells: Evolution, development and disease. Academic Press, 2014.

[3] Takabashi, Ү., Sipp, D., Enomoto, H.: Tissue interactions in neural crest cell development and disease. Science, 2013, 341(6148), 860-863.

[4] Le Douarin, N. M., Kalcheim, C.: The Neural Crest. 2nd ed. Cambridge University Press, 1999.

[5] Kuo, B. R., Erickson, C. A.: Regional differences in neural crest morphogenesis. Cell Adh. Migr., 2010, 4(4), 567-585.

[6] Betancur, P., Bronner-Fraser, M., Sauka-Spengler, T.: Assembling neural crest regulatory circuits into a gene regulatory network. Annu. Rev. Cell Dev. Biol., 2010, 26, 581-603.

[7] Simões-Costa, M., Bronner, M. E.: Establishing neural crest identity: a gene regulatory recipe. Development, 2015, 142(2), 242257.

[8] Theveneau, E., Mayor, R.: Neural crest migration: interplay between chemorepellents, chemoattractants, contact inhibition, epithelial-mesenchymal transition, and collective cell migration. Wiley Interdiscip. Rev. Dev. Biol., 2012, 1(3), 435-445.

[9] Santagati, F., Rijli, F. M.: Cranial neural crest and the building of the vertebrate head. Nat. Rev. Neurosci., 2003, 4(10), 806818.

[10] Minoux, M., Rijli, F. M.: Molecular mechanisms of cranial neural crest cell migration and patterning in craniofacial development. Development, 2010, 137(16), 2605-2621.

[11] Weston, J. A., Thiery, J. P.: Pentimento: Neural crest and the origin of mesectoderm. Dev. Biol., 2015, 401(1), 37-61.

[12] Bhatt, S., Diaz, R., Trainor, P. A.: Signals and switches in Mammalian neural crest cell differentiation. Cold Spring Harb. Perspect. Biol. 2013, 5(2), pii: a008326.

[13] Stemple, D. L., Anderson, D. J.: Isolation of a stem cell for neurons and glia from the mammalian neural crest. Cell, 1992, $71(6), 973-985$.

[14] Morrison, S. J., White, P. M., Zock, C., et al.: Prospective identification, isolation by flow cytometry, and in vivo self renewal of multipotent mammalian neural crest stem cells. Cell, 1999, 96(5), 737-749.

[15] Le Douarin, N. M., Creuzet, S., Couly, G., et al.: Neural crest cell plasticity and its limits. Development, 2004, 131(19), 46374650.

[16] Zervas, M., Millet, S., Ahn, S., et al.: Cell behaviors and genetic lineages of the mesencephalon and rhombomere 1. Neuron, 2004, 43(3), 345-357.

[17] Simon, C., Lickert, H., Götz, M., et al.: Sox 10-iCreER ${ }^{\mathrm{T} 2}$ : a mouse line to inducibly trace the neural crest and oligodendrocyte lineage. Genesis, 2012, 50(6), 506-515.

[18] Livet, J., Weissman, T. A., Kang, H., et al.: Transgenic strategies for combinatorial expression of fluorescent proteins in the nervous system. Nature, 2007, 450(7166), 56-62.

[19] Baggiolini, A., Varum, S., Mateos, J. M., et al.: Premigratory and migratory neural crest cells are multipotent in vivo. Cell Stem Cell, 2015, 16(3), 314-322.

[20] Kaltschmidt, B., Kaltschmidt, C., Widera, D.: Adult craniofacial stem cells: sources and relation to the neural crest. Stem Cell Rev., 2012, 8(3), 658-671.

[21] Dupin, E., Coelho-Aguiar, J. M.: Isolation and differentiation properties of neural crest stem cells. Cytometry A, 2013, 83(1), $38-47$.

[22] Motohashi, T., Kunisada, T.: Extended multipotency of neural crest cells and neural crest-derived cells. Curr. Top. Dev. Biol., 2015, 111, 69-95.

[23] Toma, J. G., Akbavan, M., Fernandes, K. J., et al.: Isolation of multipotent adult stem cells from the dermis of mammalian skin. Nat. Cell Biol., 2001, 3(9), 778-784.

[24] Fernandes, K. J., McKenzie, I. A., Mill, P., et al.: A dermal niche for multipotent adult skin-derived precursor cells. Nat. Cell Biol., 2004, 6(11), 1082-1093.

[25] Driskell, R. R., Giangreco, A., Jensen, K. B., et al.: Sox2-positive dermal papilla cells specify hair follicle type in mammalian epidermis. Development, 2009, 136(16), 2815-2823.

[26] Sieber-Blum, M., Schnell, L., Grim, M., et al.: Characterization of epidermal neural crest stem cell (EPI-NCSC) grafts in the lesioned spinal cord. Mol. Cell. Neurosci., 2006, 32(1-2), 67-81.

[27] Li, L., Fukunaga-Kalabis, M., Yu, H., et al.: Human dermal stem cells differentiate into functional epidermal melanocytes. J. Cell Sci., 2010, 123(6), 853-860.

[28] Widera, D., Zander, C., Heidbreder, M., et al.: Adult palatum as a novel source of neural crest-related stem cells. Stem Cells, 2009, 27(8), 1899-1910.

[29] Saito, M. T., Silvério, K. G., Casati, M. Z., et al.: Tooth-derived stem cells: Update and perspectives. World J. Stem Cells, 2015, $7(2), 399-407$.

[30] Yoshida, S., Shimmura, S., Nagoshi, N., et al.: Isolation of multipotent neural crest-derived stem cells from the adult mouse cornea. Stem Cells, 2006, 24(12), 2714-2722. 
[31] Pardal, R., Ortega-Sáenz, P., Durán, R., et al.: Glia-like stem cells sustain physiologic neurogenesis in the adult mammalian carotid body. Cell, 2007, 131(2), 364-377.

[32] Tomita, $\Upsilon$., Matsumura, K., Wakamatsu, $\Upsilon$., et al.: Cardiac neural crest cells contribute to the dormant multipotent stem cell in the mammalian heart. J. Cell Biol., 2005, 170(7), 1135-1146.

[33] Takashima, Y., Era, T., Nakao, K., et al.: Neuroepithelial cells supply an initial transient wave of MSC differentiation. Cell, 2007, 129(7), 1377-1388.

[34] Morikawa, S., Mabuchi, ., Niibe, K., et al.: Development of mesenchymal stem cells partially originate from the neural crest. Biochem. Biophys. Res. Commun., 2009, 379(4), 1114-1119.

[35] Isern, J., Garcia-Garcia, A., Martín, A. M., et al.: The neural crest is a source of mesenchymal stem cells with specialized hematopoietic stem cell niche function. Elife, 2014, 3, e03696.

[36] Van Raamsdonk, C. D., Deo, M.: Links between Schwann cells and melanocytes in development and disease. Pigment Cell Melanoma Res., 2013, 26(5), 634-645.

[37] Jessen, K. R., Mirsky, R., Lloyd, A. C.: Schwann cells: Development and role in nerve repair. Cold Spring Harb. Perspect. Biol., 2015, 7(7), pii: a020487.

[38] Yamaguchi, ., Hearing, V. J.: Melanocytes and their diseases. Cold Spring Harb. Perspect. Med., 2014, 4(5), pii: a017046.

[39] Mort, R. L., Jackson, I. J., Patton, E. E.: The melanocyte lineage in development and disease. Development, 2015, 142(4), 620632 .

[40] Buitrago-Delgado, E., Nordin, K., Rao, A., et al.: Shared regulatory programs suggest retention of blastula-stage potential in neural crest cells. Science, 2015, 348(6241), 1332-1335.
[41] Thomas, S., Thomas, M., Wincker, P., et al.: Human neural crest cells display molecular and phenotypic hallmarks of stem cells. Hum. Mol. Genet., 2008, 17(21), 3411-3425.

[42] Liu, Y., Labosky, P. A.: Regulation of embryonic stem cell selfrenewal and pluripotency by Foxd3. Stem Cells, 2008, 26(10), 2475-2484.

[43] Lin, Ү., Li, X. Y., Willis, A. L., et al.: Snaill-dependent control of embryonic stem cell pluripotency and lineage commitment. Nat. Commun., 2014, 5, 3070.

[44] Green, S. A., Simoes-Costa, M., Bronner, M. E.: Evolution of vertebrates as viewed from the crest. Nature, 2015, 520(7548), 474-482.

[45] Hall, B. K.: The neural crest as a fourth germ layer and vertebrates as quadroblastic not triploblastic. Evol. Dev., 2000, 2(1), 3-5.

[46] Achilleos, A., Trainor, P. A.: Neural crest stem cells: discovery, properties and potential for therapy. Cell Res., 2012, 22(2), 288-304.

[47] Neirinckx, V., Coste, C., Rogister, B., et al.: Concise review: adult mesenchymal stem cells, adult neural crest stem cells, and therapy of neurological pathologies: a state of play. Stem Cells Transl. Med., 2013, 2(4), 284-296.

(Uher Ferenc dr., Budapest, Karolina út 19-21., 1113 e-mail: uher.ferenc@gmail.com)

\section{A rendezvények és kongresszusok híranyagának leadása}

a lap megjelenése előtt legalább 40 nappal lehetséges, a 6 hetes nyomdai átfutás miatt. Kérjük megrendelőink szíves megértését.

A híranyagokat a következö címre kérjük: Orvosi Hetilap titkársága: Budai.Edit@akkrt.hu Akadémiai Kiadó Zrt. 